\title{
Clothing Involvement Profiles of African-American Students for Marketing Strategies
}

\author{
Terani J. Dillahunty ${ }^{1} \&$ Jung-Im Seo ${ }^{1}$ \\ ${ }^{1}$ College of Agricultural, Family and Consumer Sciences, Southern University and A\&M College, Baton Rouge, \\ LA, USA \\ Correspondence: Jung-Im Seo, College of Agricultural, Family and Consumer Sciences, Southern University and \\ A\&M College, Baton Rouge, LA, USA. E-mail: jungim_seo@subr.edu
}

Received: November 4, 2018 Accepted: November 30, 2018 Online Published: January 11, 2019

doi:10.5539/ijms.v11n1p10 URL: https://doi.org/10.5539/ijms.v11n1p10

\begin{abstract}
Successful marketing strategies for clothing business are strongly dependent on understanding the way in which consumers become involved with clothing product before making a purchasing decision. This study revealed that African-American college students have higher mean scores of clothing involvement than the other ethnic consumers have, which is caused by the highly skewed distribution pattern of clothing involvement. 240 completed data were analyzed to explain such unique characteristics of African-American students' consumption behavior using multivariate analysis of variance (MANOVA) and univariate analysis of variance (ANOVA). As a result, many of African-American college students think it is very important to choose clothing that makes them look good with the fit and style. In particular, the high-involvement groups tend to follow the latest fashion trends and dynamic clothing styles in order to create their better personal image with best-fitting clothing. Fashion magazine is one of the most important information sources to them because it usually deals with lots of the current fashion issues for young consumers compared to other information sources.
\end{abstract}

Keywords: product attributes, information sources, product involvement, African-American college students

\section{Introduction}

As steadily increasing the purchasing power of college students (Alberton, 2017), the nation's largest racial minority market, which African-American students constitute, have also much attention from marketers. The percentages of the attending African-American college students are continually increasing from $11.7 \%$ in 2000 to $14.1 \%$ in 2015 (IES: NCES, 2017). According to the Nielsen report (2016), the purchasing power of African-American college students are expected $\$ 162$ billion in the U.S. marketplace. Such African-American college students become a vitally important U.S. market due to their larger purchasing power as well as increasing population. In particular, clothing is one of fundamental products that the consumers purchase for the multipurpose reasons. In setting up marketing strategies for clothing business targeting such African-American students, it is crucial to understand the ways in which they become involved with apparel products and to understand how clothing involvement affects various consumers' purchasing behaviors. Clothing is usually considered as the high involvement product in wide variety product categories (Solomon, 1986; Goldsmith \& Emmert, 1991; Kim, 2005; Radder \& Huang, 2008). Due to its importance of these issues, clothing involvement has been discussed in a number of prior studies (O'Cass, 2000; Warrington \& Shim, 2000; Seo, Hathcode, \& Sweaney, 2001; Zhang, Li, Gong, \& Wu, 2002; O’Cass, 2004; Radder \& Huang, 2008; Seo \& Namwamba, 2014). However, very little research has been done on clothing involvement profile, which is an analysis representing the extent to which consumers exhibit various characteristics in each group's apparel purchasing behavior. This study focuses on the African-American college students' involvement profile with clothing and its implications to marketers. The unique characteristics of African-American students shown in clothing involvement profile attempt to be understood through the analysis of relationship between clothing involvement and product attributes/information sources.

\section{Literature Review}

\subsection{Involvement}

Involvement, which contains the personal attachment of products or service, is one of the most important 
constructs to understand the consumers' shopping and purchasing behaviors in retailing and marketing area. Involvement is greatly linked to a degree of personal values, inherent needs and interests (Zaichkowsky, 1986; Evrard \& Aurier, 1996; Tigert, Ring, \& King, 1976). The scale of the involvement is highly related to the different types of products and significantly engaged in different perspective on consumer shopping behaviors, consumption process, product attributes, purchasing decisions, brand consciousness, information search, brand preferences, and purchasing behaviors (Zaichkowsky, 1986; Broderick \& Muller, 1999; Traylor \& Joseph, 1984; Laurent \& Kapferer, 1985; Martin, 1998; Warrington \& Shim, 2000; Seo et al., 2001; Seo \& Namwamba, 2014; Seo, 2016). Among daily necessaries in human life, clothing is one of the most important essential products. Such clothing product is proven as one of the high involvement products in marketing and research area (Solomon, 1986; Goldsmith \& Emmert, 1991; Kim, 2005; Radder \& Huang, 2008). Many previous researches find that the concept of clothing involvement is positively or negatively associated with consumers' shopping behaviors and purchasing decision (Zaichkowsky, 1986; Warrington \& Shim, 2000; Seo et al., 2001; Seo \& Namwamba, 2014; Johnson, Banks, Smith, \& Seo, 2017; Seo, 2016). Hence, successful development of marketing strategies for clothing business is strongly dependent on a deep understanding of clothing involvement.

\subsection{Information Source}

Product information is the important tool when consumers make a purchasing decision. When consumers collect the product information, they use a variety of sources. Generally, consumers search product and service information based on print-based information (Newspaper \& magazine), broadcast information (TV \& radio), personal information sources, social media, and internet before they make a purchasing decision (Warrington \& Shim, 2000; Seo et al., 2001; Seo \& Namwamba, 2014; Refuel Agency, 2015). According to Sim and Kotsiopulos' research (1992) and Nielsen Report (2016), old consumers prefer to use newspaper to obtain a product information. However, young consumers are less likely to use newspaper information than old consumers. Rather, young consumers frequently pay attention to the personal information to obtain current product and fashion information, (Rahman \& Kharb, 2018; Seock \& Bailey, 2009). They rely on the personal information when they make a purchasing decision for their clothing (Seock \& Bailey, 2009).

The habits of shopping style in collecting product information are highly linked to levels of product involvement. Consumers with a high level of product involvement are more likely to search for product information and collect it than the low involvement group of consumers. The high involvement group of consumers used the variety of information to obtain the detailed knowledge of products and spent more time to collect product information (Mittal, 1989; Seo \& Namwamba, 2014; Johnson et al., 2017; Seo et al., 2001). They also used print publications and mass media information more frequently than the low involvement group of consumers (Shim \& Kotsiopulos, 1993).

\subsection{Product Attributes}

A product attribute is a characteristic that defines a particular product with brand image, product style, functionality, features, and so on. It usually affects the product's appeal or acceptance in the market, engaging in purchase decision. Previous studies demonstrate that the level of product involvement is significantly related to product attributes (Warrington \& Shim, 2000; Seo et al., 2001, Chandrashekaran \& Grewal, 2003; Seo \& Namwamba, 2014). The high-involvement consumers are more likely to consider the brand commitment when they purchase their clothing than low-involvement consumers (Seo \& Namwamba, 2014). According to Warrington and Shim (2000), high-involvement consumers with strong brand commitment are more likely to consider image attributes and utilitarian attributes than low-involvement consumers. Moreover, high-involvement consumers are willing to pay more for the popular brand name products (Chandrashekaran \& Grewal, 2003). There is a positive relationship between the levels of product involvement and the levels of brand commitment (Warrington \& Shim, 2000; Chandrashekaran \& Grewal, 2003; Seo \& Namwamba, 2014).

\section{Research Question}

Despite a growing number of college students and their increasing clothing consumption, the majority of apparel markers rarely pay attention to minor segments, African-American college students. This study utilizes clothing as a product variable in the surveys administered to investigate product involvement in shopping behaviors among African-American college students. The first goal of this study is to explore how unique African-American college students really are, in enduringly perceiving the importance of the clothing such as their needs, values, and interests. For this goal, the mean or the median of clothing involvement scores among African-American college students will be compared with other ethnic consumers. The second goal is to investigate the correlations between the level of product involvement and the product attributes or between the 
level of product involvement and information sources in African-American college students' shopping behaviors.

The following questions were developed for these goals:

Q1. What are the unique characteristics of apparel product involvement among African-American college students compared to other ethnic consumers?

Q2. What is the relationship between product involvement and product attributes?

Q3. What is the relationship between product involvement and information sources?

\section{Methodology}

\subsection{Sample}

This study focused on African-American college students as a target population. Convenience sampling method was applied by recruiting participants in several southeastern university campuses in US. Of the total recruited responses, 240 completed surveys were used in the data analysis. The respondents were instructed to answer the questionnaires based on their apparel shopping experiences. The questionnaire includes four main sections; product involvement, product attributes, information sources, and demographics: 8 items of clothing product involvement, 11 items of product attributes, 8 items of information sources, and 9 items relating to demographics. A large proportion of respondents were female African-Americans $(n=150,62.5 \%)$. The majority of the respondents were single $(n=214,89.2 \%)$ and undergraduate students $(n=231,96.3 \%)$. The two main age categories of respondents were 19 to $20(\mathrm{n}=94,39.2 \%)$ and 21 to $22(\mathrm{n}=83,34.6 \%)$.

\subsection{Statistics}

The collected data was statistically analyzed with IBM SPSS version 19.0 software package. Frequency distribution, Reliability (Cornbach alpha), multivariate analysis of variance (MANOVA), and univariate analysis of variance (ANOVA) were used to see how much the product involvement is correlated with the product attributes or information sources.

\section{Results}

This study used a short version of Zaichkowsky's Personal Involvement Index (PII) (1985) to measure clothing involvement for African-American college students. Respondents were asked to respond to 8 items related to clothing involvement on a 7-point semantic differential scale (e.g., "important (7)"-"unimportant (1)", "of concern (7)"-"of no concern (1)", "appealing (7)"-"unappealing (1)" etc). Using the 8 items on scale of 1 (low) to 7 (high), an average score of product involvement was calculated, ranging from 1 to 7 . A principal component analysis with varimax rotation confirmed that all 8 items meet the criterion for inclusion. Reliability (Cornbach alpha) of clothing involvement in African-American college students is $0.94(\mathrm{p}<0.001)$. This study sample obtained that an average means score of product involvement was 5.61, the median score of product involvement was 6.13, and standard deviation of product involvement was 1.45.

\section{Q1. Frequency Distribution of Product Involvement.}

Particularly noteworthy, African-American college students have higher mean $(M=5.61)$ and median $(M e d=6.13)$ scores of clothing involvement than the other ethnic consumers have. It is shown in the Table 1. Among the Asian (100\%) college students, South Korean students have 5.33 of Median (Med=5.33 of Clothing Involvement), Chinese students have 3.62 of mean score ( $M=3.62$ of Fashion Involvement), and Pakistan students have 2.60 ( $M=2.60$ with 5 Points Likert Scale as same as $M=3.64$ with 7 Points Likert Scale). Also, compared to African-American students, the majority Caucasian college students have lower mean scores such as $M=5.05$ of clothing involvement in $86 \%$ Caucasian (Seo, 2005) and $M=4.98$ of blue jeans involvement in $69.6 \%$ Caucasian (Warrington \& Shim, 2000). Interestingly, the reason of this argument can be found by the comparison of two frequency distributions of product involvement between African-American college students and majority Caucasian college students. Generally, clothing involvement follows the normal frequency distribution such as Figure 1 (b) reported in the previous research (Seo, 2005), where majority Caucasian college students were studied. However, the frequency distribution of clothing involvement in African-American college students' shopping behaviors is strongly skewed toward to high product involvement score (Figure 1 (a)) compared to the normal distribution. Hence, this result indicates that there are many of African-American college students who get very deeply involved with clothing products. To deeply understand such a unique distribution found in African-American college students, female and male case were separately considered. As shown in Figure 1 (c) and (d), the frequency distribution with female students is more strongly skewed toward to high product involvement score than male students even though both have asymmetric distributions contrary to 
the normal distribution. Female African-American college students have higher product involvement score $(M=5.80)$ than male African-American college students $(M=5.29)$. This result is consistent with the previous researches (Auty \& Elliott, 1998; Goldsberry, Shim, \& Reich, 1996) that female consumers are more involved in clothing than male consumers.

Table 1. Summary of mean and median scores of product involvement

\begin{tabular}{|c|c|c|c|c|}
\hline Source & Target/Variables & Measurement & Mean & Median \\
\hline This Study & $\begin{array}{l}\text { African-American College } \\
\text { Students/Clothing Involvement }\end{array}$ & 7 Points Likert Scale & $\mathrm{M}=5.61$ & Med $=6.13$ \\
\hline Park \& Yoo, (2018) & $\begin{array}{l}\text { Asian (South Korean)/Clothing } \\
\text { Involvement }\end{array}$ & 7 Points Likert Scale & $\mathrm{N} / \mathrm{A}$ & $\mathrm{Med}=5.33$ \\
\hline $\begin{array}{l}\text { Razzaq, Ansari, Razzaq, \& Awan, } \\
\text { (2018) }\end{array}$ & Asian (Pakistan)/Fashion Involvement & 5 Points Likert Scale & $\begin{array}{l}\mathrm{M}=2.60 \\
(\mathrm{M}=3.64 \text { after } \\
\text { converting into } 7 \\
\text { scale })\end{array}$ & N/A \\
\hline Zhang \& Kim, (2013) & Asian (China)/Fashion Involvement & 7 Points Likert Scale & $M=3.62$ & N/A \\
\hline Seo, $(2005)$ & $\begin{array}{l}86 \% \text { of Caucasian/Clothing } \\
\text { Involvement }\end{array}$ & 7 Points Likert Scale & $M=5.05$ & $\mathrm{Med}=5.00$ \\
\hline Warrington \& Shim, (2000) & $69.6 \%$ of Caucasian/Blue Jeans & 7 Points Likert Scale & $M=4.98$ & N/A \\
\hline
\end{tabular}

\section{Q2. Influence of Product Attributes}

In this study, 11 product attribute items were employed from previous researches (Lumpkin, 1985; Shim \& Kotsiopulos, 1992; Warrington \& Shim, 2000; Seo \& Namwamba, 2014). Product attributes were measured on a 7-point Likert-type scale ranging from 1 "Of no Importance," to 7 "Extremely Important". Reliability (Cornbach alpha) of product attributes for African-American college students was $0.88(\mathrm{p}<.001)$.

If the MANOVA is significant, ANOVA analysis is used to determine the differences among the variables. A summary of the statistical analysis between product involvement and product attributes is shown in Table 2 . According to Wilkes Lambda for the MANOVA, the product attributes are significantly influenced by the product involvement $(F=1.84, p \leq .001)$. The individual ANOVA indicates that 7 product attribute variables, Well-Published Image $(F=2.37, p<.1)$, Good reputation $(F=2.01, p<1)$, Brand Symbol affixed to clothing $(F=2.86, p<.05)$, Fashionability $(F=5.21, p<.001)$, Prestige $(F=7.24, p<.001)$, Familiarity with label/company $(F=3.54, p<.05)$, and Broad assortment of styles and sizes $(F=4.13, \mathrm{p}<.05)$, are significantly related to respondents' product involvement scores. That is to say, the means of those attribute variables have dramatically increased from the low level of involvement group to the high level of involvement group, as shown in Figure 2 (a). Table 2 indicates that most of product attributes seem to play an important role in product involvement (most mean scores of product attributes are higher than 4.0 on 7-point Likert-type scale). The mean scores of product attributes are increasing in accordance with the growing level of product involvement (see Figure 2 (a)).

ANOVA also revealed that some other variables such as Reasonable price, High quality construction, Good fit, and Nice color and stylish design in product attributes are still high mean scores (p.>5.0 on 7-point Likert-type scale) even though two product involvement groups were not significantly different on these variables (see Table 2). These high mean scores indicate that most of African-American college students have great interests in those variables no matter which involvement group they belong to. Clothing fit $(M=6.11)$ is the highest mean scores in the variables of product attributes.

\section{Q3. Use of Information Sources}

Eight items of information sources were adopted from the previous works (Lumpkin, 1985; Warrington \& Shim, 2000). The participators were asked to what extent they were influenced by each information source when they shopped for clothing using a 7-point Likert-type scale, ranging from 1 (not at all) to 7 (very much). Reliability (Cornbach alpha) of information sources in African-American college students is 0.82 ( $p<.001)$.

The result of statistical analysis of information sources is shown in Table 3. MANOVA analysis in Wilkes Lambda indicates that information sources are significantly influenced by product involvement $(F=1.99, p \leq .001)$. Individual ANOVA indicated that 3 variables of information sources such as Fashion magazine $(F=7.51$, $p<.001)$, TV commercials $(F=2.30, p<.1)$, and other people who wear brand name clothing $(F=2.22, p<.1)$ are significantly correlated to participators' product involvement. Most mean scores of variables in product information except for Newspaper ads $(M=2.88)$ are greater than 4.0 on 7-point Likert-type scale. The statistical 
results mean that African-American college students tend to use various information sources while they shop for clothing.

Table 2. The results of MONOVA and ANOVA between product involvement and product attributes

\begin{tabular}{|c|c|c|c|}
\hline Dependent Variables & $\begin{array}{l}\text { Mean } \\
(n=240)\end{array}$ & $\begin{array}{l}\text { Univariate } \\
F\end{array}$ & $\begin{array}{l}\text { Multivariate } \\
F\end{array}$ \\
\hline & & & $1.84 * * *$ \\
\hline Well-Published Image & 4.71 & 2.37* & \\
\hline Reasonable price & 5.79 & 1.65 & \\
\hline Good reputation & 5.39 & $2.01 *$ & \\
\hline Brand symbol affixed to clothing & 4.16 & $2.86^{* *}$ & \\
\hline Fashionability & 5.40 & $5.21^{* * *}$ & \\
\hline High quality construction & 5.62 & 1.25 & \\
\hline Good fit & 6.11 & .31 & \\
\hline Prestige & 5.11 & $7.24 * * *$ & \\
\hline Nice color and stylish design & 5.83 & 1.94 & \\
\hline Familiarity with label / company & 4.76 & $3.54 * *$ & \\
\hline Broad assortment of styles and sizes & 5.52 & $4.13 * *$ & \\
\hline
\end{tabular}

Note. Scores ranged from 1 (Of No Important) to 7 (Extremely Important).

***. Correlation is significant at the 0.001 level (2-tailed).

**. Correlation is significant at the 0.05 level (2-tailed).

*. Correlation is significant at the 0.1 level (2-tailed).
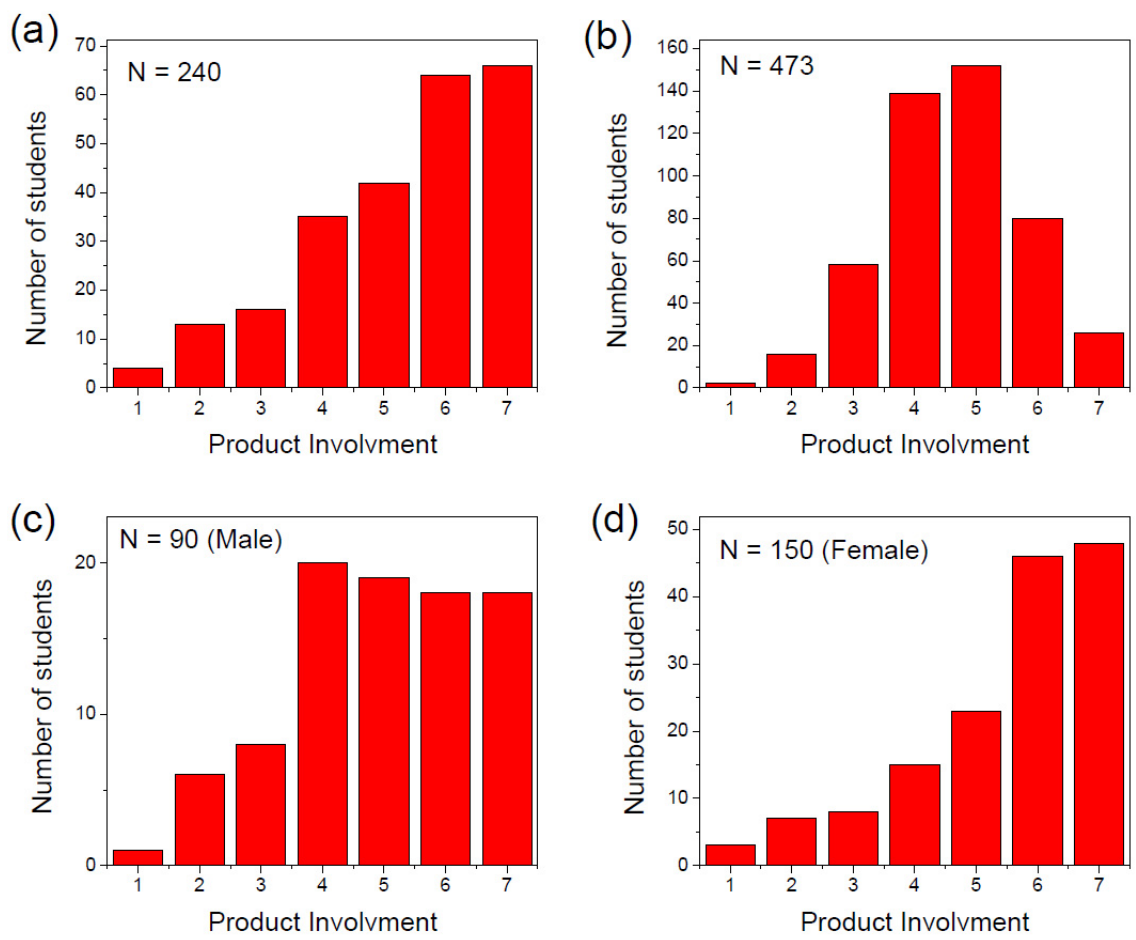

Figure 1. Distribution of number of students corresponding to each "representative" product involvement score from 1 to 7 for (a) African-American college students, (b) dominant Caucasian college students (Source: Seo, 2005), and (c) male and (d) female African-American college students. ( $\mathrm{N}$ is a sample size). 

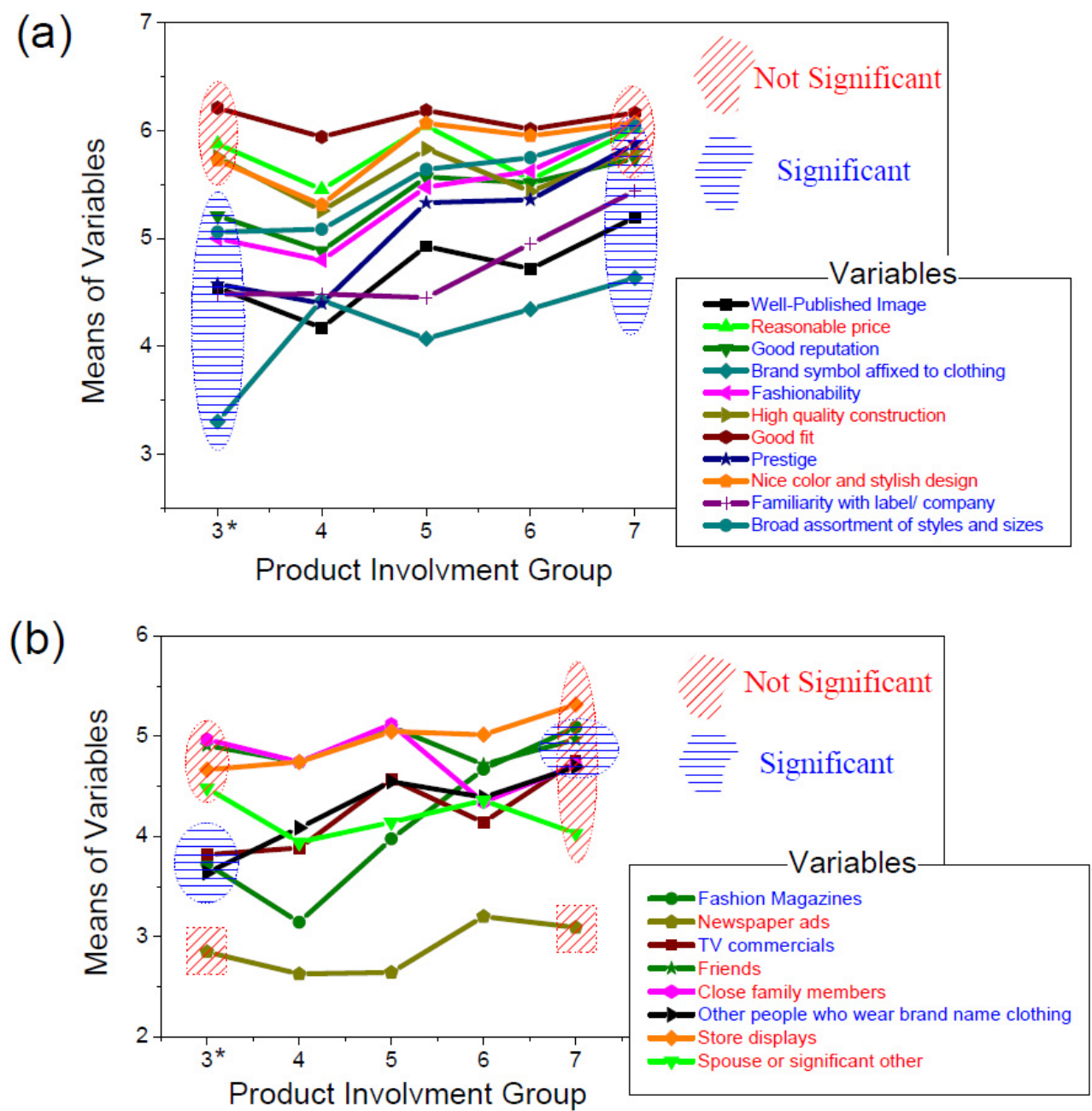

Figure 2. Mean values of variables in (a) Product Attributes and (b) Information sources corresponding to each "representative" product involvement score from 1 to 7

Note. $3^{*}$ includes product involvement scores of 1 and 2 due to their low frequencies.

Figure 2 (b) shows that the means of above significant correlated variables have steadily increased from the low-involvement group to high-involvement group. Especially, Fashion magazine $(M=4.12)$ is greatly correlated to the level of product involvement among the variables in the information sources (see Figure 2 (b)). Although the Store display $(M=4.96)$, Friends $(M=4.89)$, and Close family members $(M=4.78)$ are not significantly correlated to the level of product involvement, these variables still have high mean scores, indicating that many of African-American college students tend to intensively collect the product information during the purchasing decision. However, the Newspaper ads $(M=2.88)$ are not interesting information source among African-American college students. 
Table 3. The results of MONOVA and ANOVA between product involvement and information sources

\begin{tabular}{lccc}
\hline Dependent Variables & Mean $(\mathrm{n}=240)$ & Univariate & $\begin{array}{l}\text { Multivariate } \\
\mathrm{F}\end{array}$ \\
\hline & & $\mathbf{F}$ & $\mathbf{1 . 9 9 * * *}$ \\
Fashion Magazines & $\mathbf{4 . 1 2}$ & $\mathbf{7 . 5 1 * * *}$ & \\
Newspaper ads & 2.88 & .98 \\
TV commercials & $\mathbf{4 . 2 4}$ & $\mathbf{2 . 3 0 *}$ & \\
Friends & 4.89 & .45 \\
Close family members & 4.78 & 1.52 \\
Other people who wear brand name clothing & $\mathbf{4 . 2 7}$ & $\mathbf{2 . 2 2 *}$ & \\
Store displays & 4.96 & 1.33 \\
Spouse or significant other & 4.19 & .57 & \\
\hline
\end{tabular}

Note. Scores ranged from 1 (Of No Important) to 7 (Extremely Important).

***. Correlation is significant at the 0.001 level (2-tailed).

**. Correlation is significant at the 0.05 level (2-tailed).

*. Correlation is significant at the 0.1 level (2-tailed).

\section{Discussion}

This study discusses the ways in which African-American college students become involved with apparel products and how deeply clothing involvement has an influence on various consumers' purchasing behaviors. To understand the characteristics of African-American students' clothing involvement, the other ethnic groups' involvements are compared and discussed. As a result, African-American college students have higher mean or median of clothing/ fashion involvement than other ethnic groups have (Park \& Yoo, 2018; Razzaq et al., 2018; Zhang \& Kim, 2013; Seo, 2005; Warrington \& Shim, 2000), indicating stronger clothing (apparel) concerns of African-American students. This research explains the reason of this higher mean/median of involvement by analyzing the frequency distributions of each group's product involvement as shown in Figure 1 (a) and (b). That is, even though clothing involvement levels become higher, the number of African-American students with higher involvement level keeps increasing. This is quite unique aspect of involvement in shopping behaviors compared to other ethnic groups. This unique aspect is better represented in the frequency distribution of female African-American students' clothing involvement as shown in Figure 1 (c) and (d). In fact, female African-American college students $(M=5.80)$ are more concerned about their clothing than male African-American college students $(M=5.29)$. The result is consistent with the previous researches (Auty \& Elliott, 1998; Goldsberry et al., 1996; Kinley, Josiam, \& Lockett, 2010).

Many previous studies have reported that African-American consumers have quite different clothing shopping behaviors or clothing preferences from the other ethnic groups such as Caucasians or Hispanics (Feather, Herr, \& Ford, 1997; Grasso \& Wright III, 1997; Morris, 1993; The Inner-City Shopper, 1998). They found that African-Americans are likely to spend more money on their clothes and more time browsing for clothes than the other ethnic groups. However, those studies did not clearly explain the reasons why African-Americans have quite different shopping behaviors from the other ethnic groups. In this study, we demonstrate that such unique shopping behaviors come from the fact that African-American students are highly involved with apparel products. The high mean score of African-American students' clothing involvement supports that they are more likely to shop and browse their clothing than the other ethnic groups. This is also consistent with the previous studies that the high-involvement consumers are more likely to purchase and spend money for clothing than the low-involvement consumers (Laurent \& Kapferer, 1985; Mittal \& Lee, 1989; Seo et al., 2001; Kinley et al., 2010; Seo \& Namwamba, 2014).

The above-mentioned unique characteristics of African-American students can be explained through the analysis of relationship between clothing involvement and product attributes/information sources. According to the high mean scores of the variables in product attributes, most of the product attributes are the important criteria when African-American college consumers make a purchasing decision. In particular, Good fit $(\mathrm{M}=6.11)$ with highest mean score is the most influential attribute to the African-American students among the 11 product attribute variables. This result indicates that African-American college students strongly prefer to choose clothing that makes them look good with the fit and style. The most college students are also willing to purchase clothing with the high quality construction $(M=5.62)$ at reasonable price $(M=5.79)$ even though they have a tight budget for their clothing. They also prefer to consider the nice color and stylish design $(M=5.83)$.

As shown in Table 2 and Figure 2 (a), fashionability $(M=5.40)$ and prestige $(M=5.11)$ have the most statistically significant correlation, meaning that high-involvement groups of African-American students are much more 
sensitive to the latest fashion and new fashion trends than low-involvement groups. This result suggests that high-involvement groups of African-American students are very careful to choose their clothing. They usually prefer keeping up with the latest fashion trends and dynamic clothing styles in order to create their better personal images and uphold their social status. Because of these reasons, they also value the variables of brand symbol affixed to clothing $(M=4.16)$, familiarity with label/company $(M=4.76)$, and broad assortment of styles and sizes $(M=5.52)$, which are still significantly correlated to the level of product involvement. Even though the variables of well-published image $(M=4.71)$ and good reputation $(M=5.39)$ are relatively correlated, these statistical results indicate that the high-involvement African-American college consumers want to show their personal identities and images with a well-known brand name of clothing. It seems that they trust the famous name-brand clothing.

To maintain the latest clothing styles and fashions, African-American college students normally use various information sources. They usually get the information of the lastest fashion trend from store display $(\mathrm{M}=4.96)$ and personal information, such as friends $(\mathrm{M}=4.89)$, close family member $(\mathrm{M}=4.78)$, and spouse or significant other $(\mathrm{M}=4.19)$. However, newspaper $(\mathrm{M}=2.88)$ is rarely used for the fashion information source. These results are consistent with the previous research conducted by Sim \& Kotsiopulos (1992), Seo \& Namwamba (2014), Nielsen Report (2016), and Kinley et al. (2010).

The statistical study of information sources indicates that high-involvement groups of African-American students are more likely to seek the information about fashion and clothing trends from fashion magazine, TV commercials and other people who wear brand name clothing. In particular, among these variables, fashion magazine is most affected by the high level of clothing involvement groups, suggesting that fashion magazine is the most important information source to high-involvement groups of African-American students. Most fashion magazines usually deal with lots of the current fashion issues for young consumers. Another interesting fact is that the African-American college students also pay attention to their peer groups' clothing and brand. That is, they may acquire the information about hot issues of fashion brands from their friends and classmates or from other people who they observe.

In conclusion, we demonstrate that many of African-American college students are highly involved with clothing product compared to other ethnic consumer groups. Statistical analysis indicates that this result is strongly related to their consideration of clothing as high involvement product to create their better personal image with best-fitting and fashionable clothing. Fashion magazine is one of the most important information sources to keep up with the latest fashion trends and dynamic clothing styles.

\section{Implications}

This study suggests that clothing manufacturers and retailers targeting the minor segment of African-American college students could use these findings to understand their consumers' desire and to improve their marketing strategies in product attributes and information sources. The clothing designers may consider the unique characteristics of African-American students' consumption behavior to promote their fashion clothing brand among African-American consumers. The media markers can use these results to determine advertising media allocation in effective reaching African-American college students. Apparel retailers need to deal in the most current trends on their store because most African-American college students sensitively accept the fashionability, trend colors, and stylish design through the display window. In order to attract more African-American college students' attention, apparel manufacturers and retailers frequently announce their seasonal sale and promotional deals on clothing items through mass media.

\section{Limitations and Future Research}

A primary limitation of this study is that only southeastern part of African-American college students was used as a sample for an exploratory test of the product involvement, product attributes, and information sources. The results do not represent a generalization of all African-American college students in U.S.A. Another limitation is that only the traditional information sources related to purchasing behaviors was considered. Even though many of young African-American college students spend most of their time for using the internet, this study excludes the internet information source. The last limitation is that this research only focuses on clothing product as product involvement. Future research can include a brand consciousness, which will be significantly related to the product involvement. The future research should include broader geographic location and cross-national comparisons with gender and different generation. 


\section{Acknowledgments}

This work was supported by the USDA National Institute of Food and Agriculture, Evans-Allen project accession number: 1016007.

\section{References}

Abraham-Murali, L., \& Littrell, M. A. (1995). Consumers' perceptions of apparel quality over time: an exploratory study. Clothing and Textiles Research Journal, 13(3), 149-158. https://doi.org/10.1177/0887302X9501300301

Alberton, M. (2017, February 22). Marketing to College Students. Business.com/Marketing Strategy. Retrieved from https://www.business.com/articles/marketing-to-college-students/

Bloch, P. H. (1982). Involvement beyond the purchase process: conceptual issues and empirical investigation. Advances in Consumer Research, 9(1), 413-417.

Evrard, Y., \& Aurier, P. (1996). Identification and validation of the components of the person-object relationship. Journal of Business Research, 37(2), 127-134. https://doi.org/10.1016/0148-2963(96)00054-9

Feather, B. L., Herr, D. G., \& Ford, S. (1997). Black and white female athletes' perceptions of their bodies and garment fit. Clothing and Textiles Research Journal, 15(2), 125-128. https://doi.org/10.1177/0887302X9701500207

Goldsberry, E., Shim, S., \& Reich, N. (1996). Women 55 Years and Older: Part II. Overall Satisfaction and Dissatisfaction with the Fit of Ready-to-Wear. Clothing and Textiles Research Journal, 14(2), 121-132. https://doi.org/10.1177/0887302X9601400202

Goldsmith, R. E., \& Emmert, J. (1991). Measuring product category involvement: a multitrait-multimethod study. Journal of Business Research, 23(4), 363-371. https://doi.org/10.1016/0148-2963(91)90021-O

Grasso, M. M., \& Wright III, R. C. (1997). African-American mothers' needs, search and alternative evaluation of children's clothing. Journal of Fashion Marketing and Management, 2(1), 41-51. https://doi.org/10.1108/eb022518

IES: NCES. (2017). Fast Facts; What are the new back to school statistics for 2017? IES: National Center for Education Statistics (NCES). Retrieved from https://nces.ed.gov/fastfacts/display.asp?id=372

Johnson, C., Banks, L., Smith, D., \& Seo, J-I. (2017). The effect of product involvement on store preference and clothing benefits sought for african-american female students. Journal of Applied Business Research, 33(1), 107-114. https://doi.org/10.19030/jabr.v33i1.9871

Kim, H. S. (2005). Consumer profiles of apparel product involvement and values. Journal of Fashion Marketing and Management, 9(2), 207-220. https://doi.org/10.1108/13612020510599358

Kinley, T. R., Josiam, B. M., \& Lockett, F. (2010). Shopping behavior and the involvement construct. Journal of Fashion Marketing and Management, 14(4), 562-575. https://doi.org/10.1108/13612021011081742

Laurent, G., \& Kapferer, J. (1985). Measuring consumer involvement profiles. Journal of Marketing Research, 22(1), 41-53. https://doi.org/10.1177/002224378502200104

Martin, C. L. (1998). Relationship marketing: a high-involvement product attribute approach. Journal of Product \& Brand Management, 7(1), 6-26. https://doi.org/10.1108/10610429810209700

Mittal, B. (1989). Measuring purchase-decision involvement. Psychology \& Marketing, 6(2), 147-162. https://doi.org/10.1002/mar.4220060206

Mittal, B., \& Lee, M. S. (1989). A causal model of consumer involvement. Journal of Economic Psychology, 10(3), 363-389. https://doi.org/10.1016/0167-4870(89)90030-5

Morris, E. (1993, January). The difference in black and white. American Demographics, 44-49.

Nielsen. (2016, October 17). Nielsen 2016 Report: Young Connected and Black: African-American Millennials are driving social change and leading digital advancement. Retrieved from http://www.ethnifacts.com/Nielsen-African-American-Consumer-Report-Oct-2016.pdf

O'Cass, A. (2004). Fashion clothing consumption: antecedents and consequences of fashion clothing involvement. European Journal of Marketing, 38(7), 869-882. https://doi.org/10.1108/03090560410539294

Park, M., \& Yoo, J. (2018). Benefits of mass customized products: moderating role of product involvement and fashion innovativeness. Heliyon, 4(2), e00537. https://doi.org/10.1016/j.heliyon.2018.e00537 
Radder, L., \& Huang, W. (2008). High-involvement and low-involvement products: a comparison of brand awareness among students at a South African university. Journal of Fashion Marketing and Management, 12(2), 232-243. https://doi.org/10.1108/13612020810874908

Rahman, O., \& Kharb, D. (2018). Fashion innovativeness in India: shopping behaviour, clothing evaluation and fashion information sources. International Journal of Fashion Design, Technology and Education, 1-12. https://doi.org/10.1080/17543266.2018.1429498

Razzaq, A., Ansari, N. Y., Razzaq, Z., \& Awan, H. M. (2018). The Impact of Fashion Involvement and Pro-Environmental Attitude on Sustainable Clothing Consumption: The Moderating Role of Islamic Religiosity. SAGE Open, 8(2), 2158244018774611. https://doi.org/10.1177/2158244018774611

Refuel, Agency. (2015). 2015 College Explorer: Largest Annual College Study. Refuel Agency. Retrieved from http://research.refuelagency.com/wp-content/uploads/2016/01/College\%20Explorer\%202015\%20Final.pdf

Seo, J-I. (2005). Internet purchasing decision behavior and product involvement (Unpublished $\mathrm{PhD}$ dissertation). University of Tennessee, Knoxville, Tennessee, USA.

Seo, J-I. (2016). Internet Shopping Behaviors of Generation Y African-American Based on Apparel Production Involvement. International Business Research, 9(9), 64-77. https://doi.org/10.5539/ibr.v9n9p64

Seo, J-I. Hathcote, J. M., \& Sweaney, A. L. (2001). Casualwear shopping behavior of college men in Georgia, USA. Journal of Fashion Marketing and Management, 5(3), 208-222. https://doi.org/10.1108/EUM0000000007288

Seo, J-I., \& Namwamba, G. W. (2014) The Investigation of Product Involvement in Shopping Behaviors among Male College Students. Atlantic Marketing Journal, 3(3), 81-101.

Seock, Y. K., \& Bailey, L. R. (2009). Fashion promotions in the Hispanic market: Hispanic consumers' use of information sources in apparel shopping. International Journal of Retail \& Distribution Management, 37(2), 161-181. https://doi.org/10.1108/09590550910934290

Solomon, M. R. (1986). Deep-Seated materialism: the case of Live's 501 jeans. In R. Lutz (Ed.), Advances in Consumer Research, 13, Association for Consumer Research, Las Vegas, NV, 619-622.

The Inner-City Shopper: A Strategic Perspective. (1998). A Special Report by PricewaterhouseCoopers (PwC) and The Initiative for a Competitive Inner City. Retrieved from http://sphere.icic.org/atf/cf/\%7BC81898B2-76E9-4A18-B838-A3F65C9F06B9\%7D/99-Jan-TISS-AStrategi cProsepective.pdf

Tigert, D. J., Ring, L. J., \& King, C. W. (1976). Fashion Involvement and buying behavior: Methodological study. Advances in Consumer Research, 3, 46-52.

Traylor, M. B., \& Joseph, W. B. (1984). Measuring consumer involvement with developing a general scale. Psychology \& Marketing, 1(2), 65-77. https://doi.org/10.1002/mar.4220010207

Zaichkowsky, J. L. (1986). Conceptualizing involvement. Journal of Advertising, 15(2). https://doi.org/10.1080/00913367.1986.10672999

Zhang, B., \& Kim, J. H. (2013). Luxury fashion consumption in China: Factors affecting attitude and purchase intent. Journal of Retailing and Consumer Services, 20(1), 68-79. https://doi.org/10.1016/j.jretconser.2012.10.007

Zhang, Z., Li, Y., Gong, C., \& Wu, H. (2002). Casual wear product attributes: a Chinese consumers' perspective. Journal of Fashion Marketing and Management, 6(1), 53-62. https://doi.org/10.1108/13612020210422464

\section{Copyrights}

Copyright for this article is retained by the author, with first publication rights granted to the journal.

This is an open-access article distributed under the terms and conditions of the Creative Commons Attribution license (http://creativecommons.org/licenses/by/4.0/). 